\title{
Diagnostic Value of Endobronchial Ultrasonography in Sarcoidosis and Factors Associated with Diagnosis
}

\author{
- Önder Çetin, $\odot$ Benan Niku Çağlayan, ${ }^{2} \oplus$ Sevda Şener Cömert, ${ }^{3}$ \\ - Banu Musaffa Salepçi, ${ }^{4}$ ๑ Ferhan Karataş ${ }^{5}$
}

\author{
'Department of Chest Diseases, \\ University of Health Sciences \\ Süreyyapaşa Chest Diseases and \\ Thoracic Surgery Training and \\ Research Hospital, İstanbul, Turkey \\ ${ }^{2}$ Department of Chest Diseases, \\ Koç University Faculty of Medicine, \\ İstanbul, Turkey \\ ${ }^{3}$ Department of Chest Diseases, \\ University of Health Sciences Kartal \\ Dr. Lütfi Kırdar Training and \\ Research Hospital, İstanbul, Turkey \\ ${ }^{4}$ Department of Chest Diseases, \\ Yeditepe University Faculty of \\ Medicine, İstanbul, Turkey \\ ${ }^{5}$ Department of Chest Diseases, \\ Siverek State Hospital, \\ Şanlıurfa, Turkey \\ Submitted: 25.07 .2018 \\ Accepted: 06.11.2018
}

Correspondence: Önder Çetin Süreyyapaşa Göğüs Hastalıkları ve Göğüs Cerrahisi Eğitim ve Araştırma Hastanesi, Göğüs Hastalıkları Kliniği, İstanbul, Turkey

E-mail: drondercetin@hotmail.com

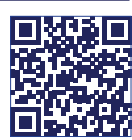

Keywords: Diagnostic value; endobronchia ultrasonography; sarcoidosis.

\section{ABSTRACT}

Objective: The aim of this study was to investigate the diagnostic value of endobronchial ultrasonography (EBUS) and factors associated with diagnosis in patients with lung sarcoidosis.

Methods: In this prospective study, EBUS transbronchial needle aspiration (TBNA) was performed for patients with a clinical and radiological suspicion of pulmonary sarcoidosis with enlarged hilar/mediastinal lymph nodes detected on a computerized tomography scan of the chest between January 2014 and September 2015.

Results: During the study period, 107 patients underwent EBUS-TBNA and I patient underwent transesophageal endoscopic ultrasonography with fine needle aspiration (EUS-FNA). Four cases determined to be non-sarcoidosis (tuberculosis) were excluded from the study. Of the 104 cases definitively diagnosed as sarcoidosis, $28.8 \%$ were male patients and $71.2 \%$ were female, with a mean age of $44.3 \pm 13$.I years. A total of $92.3 \%$ of the patients $(n=96)$ were diagnosed with EBUS-TBNA and I\% $(n=I)$ was diagnosed based on EUS-FNA results. EBUS was nondiagnostic in 7 patients and sarcoidosis was diagnosed by mediastinoscopy in 6 patients and by right supraclavicular lymph node biopsy in I patient. The sensitivity of EBUS-TBNA was $92.3 \%$, with a specificity of $100 \%$.

Conclusion: EBUS-TBNA has a high sensitivity and specificity for demonstrating granulomatous inflammation in cases of suspected sarcoidosis. Given the high diagnostic rate of EBUS-TBNA, additional invasive procedures may be unnecessary.

\section{INTRODUCTION}

Sarcoidosis is a multisystem disease with an unknown etiology. It is usually seen in young and middle-aged adults. Bilateral hilar lymphadenopathy, pulmonary infiltrations, and eye and skin lesions often occur. The diagnosis is made histopathologically with a demonstration of noncaseating epithelioid cell granuloma and the presence of clinical and radiological findings. ${ }^{[1]}$ Histopathology is very important in the diagnosis. The biopsy site varies depending on the clinical presentation of the disease. In general, the most easily accessible site with the least morbidity should be preferred. Lung and mediastinal lymph node biopsies may be performed using a fiberoptic bronchoscope with a high diagnostic value, since $95 \%$ of patients have lung involvement. The diagnostic accuracy of transbronchial lung biopsy (TBLB) is $40 \%$ to $90 \%$ when 4 to 5 biopsy specimens are obtained, depending on the experience of the bronchoscopist. ${ }^{[2]}$ In cases where the bronchial mucosa appears normal and there is no endobronchial nodule or cobblestone appearance, granuloma may be seen in the histopathological examination of endobronchial biopsy material. The diagnostic value of endobronchial biopsy in sarcoidosis has been reported to be $40 \%$ to $60 \% .{ }^{[3]}$ Samples can be taken from intrathoracic lymph nodes with conventional transbronchial needle aspiration (TBNA). 
In stage I or 2 sarcoidosis, the diagnostic value of the bronchoscopy increases when combined with TBLB and TBNA. Bilaçeroğlu et al. ${ }^{[4]}$ found that half of stage I and 2 cases and $83 \%$ of stage 3 patients had mucosal abnormalities. When the mucosal biopsy was combined with TBLB, the diagnostic value of the procedure increased from $52 \%$ to $64 \%$. In the series reported by Gupta et al., ${ }^{[5]}$ mucosal pathology was observed in one-third of the cases, and the diagnostic value of biopsy specimens retrieved from these sites was $54 \%$, while it was $20 \%$ for those obtained from normal mucosa. Similarly, as seen in the study of $\mathrm{Bi}$ laçeroğlu et al., ${ }^{[4]}$ they found that the accuracy of bronchoscopic diagnosis increased from $76 \%$ to $86 \%$ when the mucosal biopsy was combined with TBLB.

The role of bronchoscopy in the diagnosis of sarcoidosis has become even more prominent in combination with endobronchial ultrasonography (EBUS), a minimally invasive method that allows real-time sampling of mediastinal and hilar lymph nodes. The objective of this research was to investigate the diagnostic value of EBUS and related factors in patients with pulmonary sarcoidosis.

\section{MATERIAL AND METHODS}

Patients who were admitted to the outpatient clinic between January 2014 and September 2015 with the clinical and radiological suspicion of sarcoidosis and who had enlarged hilar/mediastinal lymph nodes demonstrated on computerized thorax tomography (CT) were evaluated prospectively.

The diagnosis of sarcoidosis was made based on clinical and radiological findings and histopathological examination of non-necrotic granulomatous inflammation after the exclusion of mycobacterial infection and other granulomatous diseases. Patients who did not undergo EBUS and mediastinoscopy; those with diagnoses of uncontrolled angina, uncontrolled coagulopathy, bleeding diathesis or diagnoses other than sarcoidosis; and patients who had experienced myocardial infarction within the previous 6 months were excluded from the study. Anamnesis, physical examination, chest X-ray, thorax CT, electrocardiogram, pulmonary function test (PFT) and diffusing capacity of the lungs for carbon monoxide (DLCO) evaluation, and a hemogram were performed for all of the participating patients. In all cases diagnosed with sarcoidosis by EBUS or other methods, a post-diagnosis tuberculin skin test (TST), biochemical blood tests (angiotensin-converting enzyme [ACE] and serum calcium levels), measurements of 24-hour urinary calcium level, erythrocyte sedimentation rate (ESR) and C-reactive protein, a standard clinical evaluation including tests for inflammation markers, eye and cardiology examinations were performed.

All of the patients who met the inclusion criteria underwent convex probe EBUS-TBNA hilar and mediastinal lymph node sampling. Written, informed consent was obtained from all of the participants. The procedure was performed orotracheally with the patient in the supine position under conscious sedation using an intravenous administration of midazolam and local anesthesia. A 7.5 $\mathrm{MHz}$ BF-UCI60F convex probe bronchoscope (Olympus Corp., Tokyo, Japan) and EU C2000 processor (Olympus Corp., Tokyo, Japan) was used for EBUS procedure. The lymph nodes were defined according to the regional lymph node classification system developed by Mountain. ${ }^{[6]}$ The lymph nodes numbered 2, 4, 7, 10 and II were systematically evaluated and the lymph node sizes were recorded. The procedure was performed using a 22-gauge NA20ISX-4022-C needle. Short axis diameter, characteristics of the margins, echogenicity, shape of the lymph nodes, lymph node station and number of passes were recorded for each lymph node detected. The EBUS-TBNA material was spread on slides and fixed with $95 \%$ alcohol, and the remainder of the material was prepared for a cell block in $95 \%$ alcohol and sent to the pathology laboratory. Material retrieved for a differential diagnosis of tuberculosis was sent to the microbiology laboratory for direct acidfast bacilli (AFB) examination and mycobacterium culture. The diagnosis of sarcoidosis was confirmed based on a histopathological detection of granuloma, epithelioid histiocytes, multinucleated giant cells, the absence of direct AFB, lack of growth in mycobacterial culture, and exclusion of other granulomatous diseases. Mediastinoscopy and other invasive procedures for definitive diagnosis were recommended in patients for whom a histopathological diagnosis could not be made with EBUS-TBNA. The diagnostic value, sensitivity, specificity, and negative and positive predictive values of EBUS were calculated.

\section{RESULTS}

During the study period, EBUS-TBNA was performed in 107 cases, and transesophageal endoscopic ultrasound with fine needle aspiration (EUS-FNA) was performed for I patient. As a result of the tests, 4 patients who received a non-sarcoidosis (tuberculosis) diagnosis were excluded from the study. Three of the 4 cases were diagnosed as tuberculosis based on a finding of granulomatous inflammation without necrosis using EBUS-TBNA and as a result of the regression of adenopathies with tuberculosis treatment, and the fourth patient was diagnosed based on AFB culture positivity of lymph node aspirate. The remaining 104 patients were diagnosed as sarcoidosis and these patients were included in the study. The diagnosis of sarcoidosis was established in 97 patients (93.3\%) with EBUSTBNA/EUS-FNA. In the remaining 7 patients, sarcoidosis was diagnosed in 6 cases using mediastinoscopy and in I patient with a right supraclavicular lymph node biopsy. EBUS-TBNA successfully diagnosed I patient as stage 0 , $82(97.6 \%)$ of the 84 patients ultimately diagnosed as stage I, and $13(68.4 \%)$ of 19 stage 2 cases. The stage of the disease did not significantly change the rate of effective diagnosis with EBUS ( $p>0.05)$. In all, $28.8 \%(n=30)$ of the patients were male and $71.2 \%(n=74)$ were female. The mean age was $44.3 \pm 13.1$ years (min-max: $20-76$ years). There was no significant statistical relationship between age and 
Table I. Distribution of extrapulmonary comorbidities

\begin{tabular}{lcc}
\hline Involvement & $\mathbf{n}$ & $\%$ \\
\hline Erythema nodosum & 22 & 21.2 \\
Hepatomegaly & 8 & 7.7 \\
Skin (excluding erythema nodosum) & 5 & 4.8 \\
Uveitis & 5 & 4.8 \\
Splenomegaly & 4 & 3.8 \\
Peripheral lymph node & 2 & 1.9 \\
Parotitis & $\mathrm{I}$ & 1 \\
Facial paralysis & $\mathrm{I}$ & $\mathrm{I}$ \\
\hline
\end{tabular}

gender and the diagnostic efficiency of EBUS ( $p>0.05)$.

Eleven (10.5\%) patients were asymptomatic. Among the symptomatic patients, the most common symptom was cough, followed by shortness of breath $(46.2 \%, n=48)$, fatigue $(29.8 \%, n=3 I)$, and joint pain $(26.9 \%, n=28)$. There was no statistically significant difference between the symptoms or duration of symptoms and the diagnostic efficiency of EBUS ( $p>0.05)$. Extrapulmonary involvement was found in $46.1 \%(n=48)$ of the patients. Erythema nodosum $(21.1 \%, n=22)$ was the most common indication of extrapulmonary involvement (Table I). No statistically significant difference was observed between extrapulmonary involvement and the diagnostic efficiency of EBUS $(p>0.05)$.

TST results were negative in $98 \%$ and ACE levels were elevated in $39.4 \%$ of the patients. The mean ACE level was $57.9 \pm 42.5 \mathrm{U} / \mathrm{L}$ (min-max: $|0-19| \mathrm{U} / \mathrm{L})$. The blood calcium level was high in $3.8 \%(n=4)$ of the cases and the mean value was $9.6 \pm 0.9 \mathrm{mg} / \mathrm{dL}$ (min-max: $6.02-11.8 \mathrm{mg} / \mathrm{dL}$ ). The 24-hour urinary calcium level was high in $11.5 \%(n=12)$ and the mean measurement was $185.6 \pm 131.7 \mathrm{mg} / 24$ hours (min-max: $3.8-714 \mathrm{mg} / 24$ hours). An increased ESR was detected in $57.7 \%(n=60)$ cases, and the mean ESR was $35.9 \pm 28.6 \mathrm{~mm} /$ hour (min-max: 4-104 mm/hour). A positive correlation was found between the ACE level and the diagnostic efficiency of EBUS ( $p=0.013)$.
Table 3. Distribution of lymph nodes sampled using EBUS-TBNA

\begin{tabular}{lcc}
\hline Localization & $\mathbf{n}$ & $\%$ \\
\hline Subcarinal-7 & 98 & 40 \\
Right lower paratracheal-4R & 68 & 28 \\
Left interlobar-I IL & 50 & 21 \\
Right interlobar-IIR & 19 & 8 \\
Left lower paratracheal-4L & 6 & 3 \\
Total & 241 & 100 \\
\hline
\end{tabular}

EBUS-TBNA: Endobronchial ultrasonography-transbronchial needle aspiration.

PFT results indicated that there was respiratory dysfunction in $22.2 \%$ of the patients, categorized as restrictive $(12.5 \%, n=13)$, obstructive $(7.7 \%, n=8)$, or a mixed pattern $(2 \%, n=2)$. When analyzed by stage, respiratory dysfunction was present in $20.3 \%(n=17)$ of stage $I$ and $31.6 \%$ $(n=6)$ of stage 2 cases. DLCO testing revealed diffusion disorder in $20.2 \%(n=21)$ of the patients, with a mean DLCO value of $91 \pm 23.8$ (min-max: $18-181$ ). DLCO/alveolar volume measure was normal or high in $85.6 \%$ of the patients $(n=89)$ and low in $14.4 \%(n=15)$. The mean DLCO/ alveolar volume value was $96 \pm 21.5$ (min-max: $22-170$ ) (Table 2). There was no statistically significant relationship between PFT and DLCO and the diagnostic efficiency of EBUS $(p>0.05)$.

Material was obtained with EBUS from a total of 24I lymph nodes from 103 patients. When the lymph nodes were evaluated according to their location, $98(40 \%)$ of the 24 I were subcarinal, $68(28 \%)$ were in the right lower paratracheal region, $50(21 \%)$ in the left interlobar region, $19(8 \%)$ in the right interlobar, and $6(3 \%)$ in the left lower paratracheal region (Table 3). The diagnostic efficiency of EBUS for paratracheal lymph nodes was found to be statistically significant $(p=0.013)$. The shape, echogenicity, and characteristics of the margins of lymph nodes were also evaluated using EBUS. The nodes were round in shape in $54 \%(n=130)$, multiple conglomerate configurations in

Table 2. Patient pulmonary function test and diffusing capacity of the lungs for carbon monoxide (single breath) results according to stage

\begin{tabular}{|c|c|c|c|c|}
\hline & Stage $0(n=1)$ & Stage I $(n=84)$ & Stage $2(n=19)$ & Total $(n=104)$ \\
\hline & n (\%) & n (\%) & n (\%) & n (\%) \\
\hline \multicolumn{5}{|c|}{ Pulmonary function test } \\
\hline Normal & $I(I)$ & $67(79.8)$ & $13(68.4)$ & 81 (77.8) \\
\hline Obstruction & - & $6(7.1)$ & $2(10.5)$ & $8(7.7)$ \\
\hline Restriction & - & $10(11.9)$ & $3(15.7)$ & $13(12.5)$ \\
\hline Mixed & - & I (I.2) & I (5.4) & $2(2)$ \\
\hline \multicolumn{5}{|c|}{$\begin{array}{l}\text { Diffusing capacity of the lungs for } \\
\text { carbon monoxide (single breath) }\end{array}$} \\
\hline Decreased & $I(I)$ & $13(15.4)$ & $7(36.8)$ & $21(20.2)$ \\
\hline Normal & - & $67(79.8)$ & II (57.9) & $78(75)$ \\
\hline Increased & - & $4(4.8)$ & I (5.3) & $5(4.8)$ \\
\hline
\end{tabular}


$40 \%(n=97)$, hypoechoic in $46.4 \%(n=112)$, heterogeneous in $27.3 \%(n=66)$, isoechoic in $23.2 \%(n=56)$, prominent margins in $95.4 \%(n=230)$, and indistinct margins in $4.6 \%$ $(n=I I)$ of the cases (Table 4). No statistically significant correlation was found between the size, shape, echogenicity, or marginal features of lymph nodes and the diagnostic efficiency of EBUS ( $p>0.05)$.

A total of 24I lymph nodes in 103 patients were sampled using EBUS. The mean number of lymph nodes per patient was 2.33. A total of 632 aspiration biopsies were performed from 24I lymph nodes. The mean number of aspirations performed per lymph node was 2.62 , and 6.13 aspirations per patient (Table 5). The diagnostic efficiency of
EBUS significantly increased from I to 2 passes $(p=0.004)$ and from 2 to 3 passes per lymph node $(p=0.004)$. The increase in the number of sampled lymph node stations did not result in a significant increase in the diagnostic efficiency of EBUS ( $p>0.05)$.

The cytological evaluation of the EBUS lymph node samples revealed granulomatous disease localized in right lower paratracheal lymph nodes in $73.6 \%(n=50)$, left lower paratracheal lymph nodes in $83.3 \%(n=5)$, subcarinal lymph nodes in $62.2 \%(n=61)$, right interlobar lymph nodes in $52.7 \%$ ( 10$)$, and left interlobar lymph nodes in $56 \%$ (28) of the cases (Table 6). The use of a common cell block for lymph node samples with negative smear results

Table 4. Distribution of morphological characteristics of lymph nodes sampled using EBUS-TBNA by location

\begin{tabular}{|c|c|c|c|c|c|}
\hline & $4 R$ & 4L & 7 & IIR & IIL \\
\hline & n (\%) & n (\%) & n (\%) & n (\%) & n (\%) \\
\hline \multicolumn{6}{|l|}{ Shape } \\
\hline Round & $4 I(63 . I)$ & $3(50)$ & $39(39.8)$ & $9(47.4)$ & $38(76)$ \\
\hline Multiple conglomerate & $23(35.4)$ & $3(50)$ & $58(59.2)$ & $4(21.1)$ & $9(18)$ \\
\hline Oval & I (I.5) & - & I (I) & $6(31.5)$ & $3(6)$ \\
\hline \multicolumn{6}{|l|}{ Echogenicity } \\
\hline Hypoechoic & $4 I(63.1)$ & $3(50)$ & $31(31.6)$ & $12(63.2)$ & $25(50)$ \\
\hline Heterogeneous & $9(13.8)$ & I (I6.7) & 45 (45.9) & - & II (22) \\
\hline Isoechoic & $14(2 \mid .6)$ & $2(33.3)$ & $21(21.4)$ & $7(36.8)$ & $12(24)$ \\
\hline Hyperechoic & I (I.5) & - & I (I) & - & $2(4)$ \\
\hline \multicolumn{6}{|l|}{ Margins } \\
\hline Indeterminate & $2(2.9)$ & - & $6(6.2)$ & I (5.3) & $2(4)$ \\
\hline Prominent & $66(97.1)$ & $6(100)$ & $92(93.8)$ & $18(94.7)$ & $48(96)$ \\
\hline
\end{tabular}

EBUS-TBNA: Endobronchial ultrasonography-transbronchial needle aspiration.

Table 5. Dimensions of lymph nodes measured with EBUS and mean $( \pm S D)$ number of passes performed

\begin{tabular}{lcccc}
\hline Lymph node & \multicolumn{1}{c}{ Size } & & Diameter & $\frac{\text { Number of passes }}{n}$ \\
\cline { 2 - 2 } & Mean \pm SD & & Minimum-Maximum & Mean \pm SD \\
\hline Subcarinal-7 & $2.06 \pm 0.93 \mathrm{~cm}$ & $1-4 \mathrm{~cm}$ & $2.88 \pm 0.59$ \\
Right lower paratracheal-4R & $1.98 \pm 0.89 \mathrm{~cm}$ & $\mathrm{I}-5 \mathrm{~cm}$ & $1.75 \pm 1.4$ \\
Left lower paratracheal-4L & $2.16 \pm 1.60 \mathrm{~cm}$ & $\mathrm{I}-5 \mathrm{~cm}$ & $1.83 \pm 0.75$ \\
Right interlobar-IIR & $1.58 \pm 0.47 \mathrm{~cm}$ & $\mathrm{I}-2.5 \mathrm{~cm}$ & $2.1 \mathrm{I} \pm 0.45$ \\
Left interlobar-IIL & $1.63 \pm 0.5 \mathrm{~cm}$ & $0.5-3 \mathrm{~cm}$ & $2.47 \pm 0.6 \mathrm{I}$ \\
\hline
\end{tabular}

EBUS: Endobronchial ultrasonography; SD: Standard deviation.

Table 6. Smear results by location of lymph nodes sampled using EBUS-TBNA

\begin{tabular}{|c|c|c|c|c|c|}
\hline & $4 R$ & 4L & 7 & IIR & IIL \\
\hline & n (\%) & n (\%) & n (\%) & n (\%) & n (\%) \\
\hline Granulomatous disease & $50(73.6)$ & $5(83.3)$ & $61(62.2)$ & $10(52.7)$ & $28(56)$ \\
\hline Lymphocytes & $9(13.2)$ & I (I6.7) & $26(26.5)$ & $7(36.8)$ & $9(18)$ \\
\hline Inadequate material & $9(13.2)$ & - & II (II.3) & $2(10.5)$ & $13(26)$ \\
\hline
\end{tabular}

EBUS-TBNA: Endobronchial ultrasonography-transbronchial needle aspiration. 
Table 7. Results of 10 studies where EBUS was performed with the initial diagnosis of sarcoidosis

\begin{tabular}{|c|c|c|c|c|c|c|}
\hline Author & Type of study & $\begin{array}{l}\text { Number of } \\
\text { patients }\end{array}$ & Stage & $\begin{array}{l}\text { Median (range) } \\
\text { size of lymph } \\
\text { nodes }(\mathbf{m m})\end{array}$ & $\begin{array}{l}\text { Number of } \\
\text { lymph nodes }\end{array}$ & $\begin{array}{c}\text { EBUS diagnostic } \\
\text { sensitivity } \\
\%\end{array}$ \\
\hline Garwood $[7]$ & Prospective & 50 & $0-4$ & $4-40(16)$ & 82 & 85 \\
\hline $\mathrm{Plit}^{[8]}$ & Retrospective & 40 & 1.2 & $8-36(16)$ & 61 & 84 \\
\hline Wong ${ }^{[9]}$ & Prospective & 65 & 1.2 & 7-37 (20.5) & 77 & 87.5 \\
\hline Tremblay ${ }^{[10]}$ & Prospective & 24 & 1.2 & 16.5 & 4 (Mean) & 83.3 \\
\hline $\mathrm{Oki}^{[1]]}$ & Prospective & 62 & 1.2 & $10-33(16.2)$ & 123 & 94 \\
\hline Nakajima $^{[12]}$ & Retrospective & 38 & 1.2 & $7.3-30$ & 51 & 91.4 \\
\hline $\operatorname{Sun}^{[13]}$ & Prospective & 120 & 1.2 & $6-32(16)$ & 284 & 93.6 \\
\hline Çağlayan ${ }^{[14]}$ & Prospective & 72 & 1.2 & 19.6 & 121 & 79.5 \\
\hline Gupta $^{[15]}$ & Prospective & 62 & 1.2 & - & - & 74.5 \\
\hline Navani[ ${ }^{[16]}$ & Prospective & 40 & 1.2 & $10-45(24)$ & 71 & 85 \\
\hline
\end{tabular}

EBUS: Endobronchial ultrasonography.

was found to be statistically significant in the identification of granulomatous inflammation $(\mathrm{p}<0.00 \mathrm{I})$.

\section{DISCUSSION}

The diagnosis of sarcoidosis uses a histopathological demonstration of epithelioid cell noncaseating granulomas together with clinical and radiological findings and the exclusion of other similar diseases. ${ }^{[1]}$ In $95 \%$ of patients, diagnosis is established by pulmonary physicians due to intrathoracic involvement. Pulmonary physicians often use bronchoscopic techniques, such as endobronchial mucosa biopsy, TBLB, and TBNA for diagnosis because of their high diagnostic efficiency. The role of bronchoscopy in the diagnosis of sarcoidosis with EBUS, which is a minimally invasive method that allows real-time sampling of mediastinal and hilar lymph nodes, has become more prominent. In our study, 103 patients with mediastinal and/or hilar lymphadenopathy and a pre-diagnosis of sarcoidosis were diagnosed with EBUS-TBNA and I patient underwent EUS-FNA. The sensitivity of EBUS-TBNA in this study was determined to be $92.3 \%$, the specificity $100 \%$, and the positive predictive value $100 \%$. The diagnostic value of EBUSTBNA was $100 \%(1 / 1)$ in stage 0 cases, $97.6 \%(82 / 84)$ in stage I cases, and $68.4 \%$ (13/19) in stage 2 cases.

In the literature, the reported diagnostic value of EBUSTBNA in sarcoidosis has ranged between $74.5 \%$ and 94\% (Table 7)..$^{[7-16]}$ Garwood et al. ${ }^{[7]}$ performed EBUS in 50 patients with the initial diagnosis of sarcoidosis, and a diagnosis of $4 \mathrm{I}$ (85\%) patients could be made using EBUS-TBNA. The success was greater in detecting stage I patients (94\%) relative to stage 2 patients $(80 \%){ }^{[7]}$ Similarly, in our study, the rate of diagnosis was greater in stage I patients relative to stage 2 patients ( $97.6 \%$ vs $68.4 \%$ ), without any statistically significant intergroup difference $(p>0.05)$. Wong et al. ${ }^{[9]}$ performed EBUS-TBNA in $65 \mathrm{pa}-$ tients, and 56 patients were diagnosed with sarcoidosis; the diagnostic accuracy of EBUS-TBNA was $87.5 \%$. Tremblay et al. ${ }^{[10]}$ examined the diagnostic efficiency of TBNA with a 19-gauge needle in 50 patients with suspected sarcoidosis and performed EBUS-TBNA in 24 and TBNA in 26. The diagnostic sensitivity of EBUS-TBNA was determined to be $83.3 \%$, and the sensitivity of TBNA alone was $60.9 \%$. Oki et al. ${ }^{[1]}$ reported that the use of TBLB after EBUS-TBNA in 62 patients suspected to have sarcoidosis resulted in a finding of epithelioid cell granuloma without caseating necrosis in 51 (94\%) patients. EBUS-TBNA diagnosed sarcoidosis in 37 (97\%) of 38 stage I patients and I4 (88\%) of 16 stage 2 patients. The sensitivity and specificity of EBUS-TBNA was $94 \%$ and $100 \%$, respectively. TBLB diagnosed sarcoidosis in 19 (37\%) of 52 patients. Nakajima et al. ${ }^{[2]}$ consecutively performed bronchoalveolar lavage, TBLB, and EBUS-TBNA in 38 patients during the same session. Fourteen patients (40\%) were diagnosed with TBLB and 32 patients with EBUS-TBNA, with a sensitivity of $91.4 \%$. In a study ofn 120 patients conducted by Sun et al. ${ }^{[13]}$ granulomatous inflammation was detected in 104 (93.6\%) of III patients diagnosed with sarcoidosis using EBUS-TBNA a diagnostic sensitivity of $93.6 \%$, specificity of $100 \%$, and positive and negative predictive values of $100 \%$ and $94.3 \%$, respectively, were calculated for EBUS-TBNA.

Çağlayan et al. ${ }^{[14]}$ studied 72 patients who underwent EBUS-TBNA and arrived at the diagnosis of sarcoidosis in 35 patients and tuberculosis in 16; the sensitivity of EBUS-TBNA was calculated as $79.5 \%$ (74.1\% for stage I and $92.3 \%$ for stage 2 ). Gupta et al. ${ }^{[15]}$ randomized 130 patients into EBUS-TBNA $(n=68)$ and conventional TBNA $(n=62)$ groups, and all of the patients underwent endobronchial mucosa biopsy and TBLB. Granulomatous inflammation was demonstrated in 30 patients who underwent TBNA, and the rate of diagnosis was estimated as $48.4 \%$. EBUS-TBNA revealed granulomatous inflammation in $4 \mathrm{I}$ patients, and the rate of diagnosis was $74.5 \%$. When EBUS-TBNA was combined with endobronchial mucosa biopsy and TBLB, the rate of diagnosis was $92.7 \%$. Navani et al. ${ }^{[16]}$ performed EBUS-TBNA followed by TBLB and endobronchial mucosa biopsy in 40 suspected sarcoidosis patients. The sensitivity of EBUS-TBNA was found to be 
$85 \%$ (89\% in stage $\mathrm{I}$ and $78 \%$ in stage 2 ). Plit et al. ${ }^{[8]}$ found that among 40 patients with suspected sarcoidosis EBUSTBNA established the diagnosis in $84 \%(n=31 / 37)$, TBLB in $78 \%(n=29 / 37)$, and endobronchial mucosa biopsy in $27 \%$ $(n=10 / 37)$. EBUS-TBNA established the diagnosis in $80 \%$ of stage $I$ and $86 \%$ of stage 2 patients.

In our study, a total of 24I lymph nodes were sampled using EBUS. The most frequently sampled lymph nodes were subcarinal lymph nodes $(n=98,40 \%)$ with a median diameter of $20.6 \mathrm{~mm}$, followed by right lower paratracheal lymph nodes $(n=68,28 \%)$ with a median diameter of 19.8 $\mathrm{mm}$. Similarly, the most frequently cited samples in the literature are subcarinal and right lower paratracheal lymph nodes. ${ }^{[8,9,11,12]}$ Wong et al. ${ }^{[9]}$ used EBUS to measure 67 mediastinal and 10 hilar lymph node samples and reported a median diameter of $20.5 \mathrm{~mm}$. The most frequently sampled among the 77 lymph nodes were subcarinal lymph nodes $(n=29,38 \%)$ with a median diameter of $22.4 \mathrm{~mm}$, followed by right lower paratracheal lymph nodes $(n=16$, $21 \%$ ) with a median diameter of $15.8 \mathrm{~mm}$. Oki et al. ${ }^{[1]}$ sampled 123 lymph nodes with EBUS-TBNA and found a mean diameter of $16.2 \mathrm{~mm}$. The most often sampled were right lower paratracheal and subcarinal lymph nodes. A total of 409 lymph nodes were sampled in a study conducted by Ozgul et al.,, ${ }^{[1]}$ including 158 subcarinal and 84 right lower paratracheal lymph nodes with a median diameter varying between 5 and $70 \mathrm{~mm}$. Thirty (7.3\%) lymph nodes had a short axis of less than I cm, while 379 (92.7\%) lymph nodes above $1 \mathrm{~cm}$ were found. ${ }^{[17]}$ In our study, subcarinal and paratracheal lymph nodes were most frequently sampled and the diagnostic accuracy of paratracheal lymph nodes was statistically significant $(p=0.013)$. There was no statistically significant relationship between lymph node size and the diagnostic efficiency of EBUS ( $p>0.05)$. The use of a common cell block to show granulomatous inflammation in smear- negative lymph node samples was statistically significant $(p<0.001)$.

In the present study, a total of 632 aspirations were performed from 241 lymph nodes in 130 patients using EBUSTBNA. The mean number of lymph nodes per patient was 2.33 , the number of aspirations per lymph node was 2.62 , and the number of aspirations per patient was 6.13. Wong et al. ${ }^{\left[{ }^{[]}\right.}$reported 1.2 lymph nodes sampled per patient. Garwood et al. ${ }^{[7]}$ noted that the rate of diagnosis per lymph node exceeded $80 \%$ after 5 passes; however, it did not increase further after 7 passes. Sun et al. ${ }^{[13]}$ found that the diagnostic efficiency of EBUS-TBNA was related to the stage of the disease, but the number of sampled lymph node stations was found to be unrelated to the number of passes per patient. The length of the short axis of the node, more than I pass per lymph node, and the stage of the disease were determined to be independent risk factors associated with positive pathology. Diagnostic efficiency plateaued at 3 aspirations per lymph node and decreased after 5 aspirations. Çağlayan et al. ${ }^{[14]}$ studied 208 passes performed on 121 lymph nodes of 72 patients. The median number of passes per patient was
2.88, and the median pass count per lymph node was I.7I. The sensitivity was $72.7 \%$ when sampling was performed only from a single lymph node station and increased to $85.3 \%$ in samplings made from multiple lymph node stations. When only a single pass per patient was performed, the sensitivity was $50 \%$, but when more than one pass was performed, the sensitivity increased to $83 \%$. In our study, as the number of passes per lymph node increased, the diagnostic efficiency of EBUS showed a statistically significant increase $(p=0.002)$. However, the increase in the number of lymph nodes in the sample did not increase the diagnostic efficiency of EBUS ( $p>0.05)$.

Sarcoidosis can be seen in both sexes, and in all races and age groups. In our country, the average patient age was 44 years in a study performed by a study group of the Tuberculosis and Thorax Association. ${ }^{[18]}$ Two-thirds of their study group was female, and the onset of sarcoidosis in women was found to be 10 years earlier than men. Similarly, in our study, $71.2 \%$ of our patients were female with an average age of 44.3 years. The symptom distribution of our patients was compared with the study of TTD Sarcoidosis Study Group. In our study, the mean ACE level was 57.9 $\pm 42.5 \mathrm{U} / \mathrm{L}$ (min-max: 10-191 U/L). A positive correlation was found between the $A C E$ value and the diagnostic efficiency of EBUS $(p=0.013)$. The sensitivity of ACE measurement is low, however, so it is not diagnostic. The sensitivity and specificity rates have been reported as was $57 \%$ and $90 \%$, respectively. ${ }^{[2]}$

In conclusion, EBUS-TBNA has high sensitivity and specificity in demonstrating granulomatous inflammation in patients with suspected sarcoidosis, and this diagnostic capability can make other invasive procedures unnecessary.

Ethics Committee Approval

Approved by the local ethics committee.

Informed Consent

Prospective study.

Peer-review

Internally peer-reviewed.

Conflict of Interest

None declared.

Authorship Contributions

Concept: B.N.Ç., S.Ş.C.; Design: B.S., Ö.Ç..; Data collection \&/or processing: F.K.; Analysis and/or interpretation: B.Ç., S.Ş.C.; Literature search: Ö.Ç., F.K.; Writing: Ö.Ç., S.Ş.C.; Critical review: B.Ç., B.S.

\section{REFERENCES}

1. Statement on sarcoidosis. Joint Statement of the American Thoracic Society (ATS), the European Respiratory Society (ERS) and the World Association of Sarcoidosis and Other Granulomatous Disorders (WASOG) adopted by the ATS Board of Directors and by the ERS Executive Committee, February 1999. Am J Respir Crit Care Med 1999;160:736-55.

2. Judson MA. The diagnosis of sarcoidosis. Clin Chest Med 
2008;29:415-27. [CrossRef]

3. Moller DR. Systemic sarcoidosis. In: Fishman AP, Elias JA, Grippi MA, Jenior RM, Pack AI, editors. Fishman's Pulmonary Diseases and Disorders. 4th edition. London: McGraw-Hill; 2008. p. 1125-42.

4. Bilaçeroğlu S, Perim K, Günel O, Cağirici U, Büyükşirin M. Combining transbronchial aspiration with endobronchial and transbronchial biopsy in sarcoidosis. Monaldi Arch Chest Dis 1999;54:217-23.

5. Gupta D, Mahendran C, Aggarwal AN, Joshi K, Jindal SK. Endobronchial vis a vis transbronchial involvement on fiberoptic bronchoscopy in sarcoidosis. Sarcoidosis Vasc Diffuse Lung Dis 2001;18:91-2.

6. Mountain CF, Dresler CM. Regional lymph node classification for lung cancer staging. Chest 1997;111:1718-23. [CrossRef]

7. Garwood S, Judson MA, Silvestri G, Hoda R, Fraig M, Doelken P. Endobronchial ultrasound for the diagnosis of pulmonary sarcoidosis. Chest 2007;132:1298-304. [CrossRef]

8. Plit M, Pearson R, Havryk A, Da Costa J, Chang C, Glanville AR. Diagnostic utility of endobronchial ultrasound-guided transbronchial needle aspiration compared with transbronchial and endobronchial biopsy for suspected sarcoidosis. Intern Med J 2011;42:434-8. [CrossRef]

9. Wong M, Yasufuku K, Nakajima T, Herth FJ, Sekine Y, Shibuya K, et al. Endobronchial ultrasound: new insight for the diagnosis of sarcoidosis. Eur Respir J 2007;29:1182-6. [CrossRef]

10. Tremblay A, Stather DR, MacEachern P, Khalil M, Field SK. A randomized trial of standard vs endobronchial ultrasonography-guided transbronchial needle aspiration in patients with suspected sarcoidosis. Chest 2009;136:340-6. [CrossRef]

11. Oki M, Saka H, Kitagawa C, Kogure Y, Murata N, Ichihara S, et al. Prospective study of endobronchial ultrasound-guided transbronchial needle aspiration of lymph nodes versus transbronchial lung biopsy of lung tissue for diagnosis of sarcoidosis. J Thorac Car- diovasc 2012;143:1324-9. [CrossRef]

12. Nakajima T, Yasufuku K, Kurosu K, Takiguchi Y, Fujiwara T, Chiyo $\mathrm{M}$, et al. The role of EBUS-TBNA for the diagnosis of sarcoidosiscomparisons with other bronchoscopic diagnostic modalities. Respir Med 2009;103:1796-800. [CrossRef]

13. Sun J, Yang H, Teng J, Zhang J, Zhao H, Garfield DH, et al. Determining factors in diagnosing pulmonary sarcoidosis by endobronchial ultrasound-guided transbronchial needle aspiration. Ann Thorac Surg 2015;99:441-5. [CrossRef]

14. Çağlayan B, Salepçi B, Fidan A, Kıral N, Cömert SS, Yavuzer D, et al. Sensitivity of convex probe endobronchial sonographically guided transbronchial needle aspiration in the diagnosis of granulomatous mediastinal lymphadenitis. J Ultrasound Med 2011;30:1683-9.

15. Gupta D, Dadhwal DS, Agarwal R, Gupta N, Bal A, Aggarwal AN. Endobronchial ultrasound-guided transbronchial needle aspiration vs conventional transbronchial needle aspiration in the diagnosis of sarcoidosis. CHEST 2014;146:547-56. [CrossRef]

16. Navani N, Booth HL, Kocjan G, Falzon M, Capitanio A, Brown JM, et al. Combination of endobronchial ultrasound-guided transbronchial needle aspiration with standard bronchoscopic techniques for the diagnosis of stage I and stage II pulmonary sarcoidosis. Respirology 2011;16:467-72. [CrossRef]

17. Ozgul MA, Cetinkaya E, Kirkil G, Ozgul G, Abul Y, Acat M, et al. Lymph node characteristics of sarcoidosis with endobronchial ultrasound. Endosc Ultrasound 2014;3:232-7. [CrossRef]

18. Kiter G, Musellim B, Cetinkaya E, Türker H, Kunt Uzaslan E, Yenturk E, et. Al; Sarcoidosis Working Group of Turkish Thoracic Society. Clinical Presentations and Diagnostic Work-up in a Series of Turkish Sarcoidosis Cases (clinics and diagnosis of sarcoidosis). Tuberk Toraks 2011;59:248-58. [CrossRef]

\section{Sarkoidozda Endobronşiyal Ultrasonografinin Tanı Değeri ve Tanıyla Iliş̧kili Faktörler}

Amaç: Çalışmamızda akciğer sarkoidozu olan olgularda endobronşiyal ultrasonografinin (EBUS) tanı değerini ve tanıyla ilişkili faktörleri araştırmayı amaçladık.

Gereç ve Yöntem: İleriye yönelik olarak planlanan bu çalışmada, Ocak 2014 ile Eylül 2015 tarihleri arasında polikliniğimize başvuran, klinik ve radyolojik olarak akciğer sarkoidozu düşünülen, toraks bilgisayarlı tomografisinde (BT) büyümüş hiler/mediastinal lenf bezi saptanarak EBUS transbronşiyal iğne aspirasyonu (TBIA) yapılan olguları inceledik.

Bulgular: Çalışma periyodu içersinde 107 hastaya EBUS-TBIA, bir hastaya endoskopik ultrason eşliğinde transözofagial iğne aspirasyonu (EUS-TÖIA) yapıldı. Sarkoidoz dışı tanı (tüberküloz) alan dört hasta çalışmadan çıkarıldı. Sarkoidoz tanısı alan 104 hastanın \%28.8'ini erkek, \%7I.2'sini kadın hastalar oluşturmaktaydı. Yaş ortalaması 44.3ะ13.I yıl saptandı. Yüz dört hastanın 96'sına (\%92.3) EBUS-TBIA, bir hastaya (\% I) EUS-TÖIA ile sarkoidoz tanısı kondu. Tanı elde edilemeyen yedi hastanın altısına mediastinoskopi bir hastaya sağ supraklavikular lenf nodu biyopsisi ile sarkoidoz tanısı kondu. EBUS-TBIA'nın sensitivitesi \%92.3 spesifitesi \% 100 bulundu.

Sonuç: Sarkoidoz şüphesi olan hastalarda granülomatöz enflamasyonu göstermede EBUS-TBi̇A yüksek sensitivite ve spesifiteye sahip olup, yüksek tanı oranı ile ileri invaziv işlemleri gereksiz kıldığı sonucuna varılmıştır.

Anahtar Sözcükler: Endobronşiyal ultrasonografi; sarkoidoz; tanı değeri. 